animals, either as a whole or at the various times of killing. Grain counts were therefore made, but again no significant differences were found.

\section{Discussion}

Since this study was begun Danowski et al. (1962) have shown that when leucine and tolbutamide are taken together the degree of hypoglycaemia is no greater than with tolbutamide alone, but the addition of leucine prolonged the duration of the hypoglycaemia. The leucine also increased tolbutamide-induced hypophosphataemia. Danowski et al. therefore suggested that sufficient extra insulin was released to produce further hypophosphataemia, but not further hypoglycaemia. Our studies have shown that tolbutamide can " sensitize" normal individuals to the hypoglycaemic effect of leucine, so it does appear that this is a general property of the sulphonylureas. Fajans et al. (1963) have clearly demonstrated that leucine-induced hypoglycaemia after chlorpropamide administration is associated with increased circulating insulin (immuno-assay) levels. They also found that, although oral leucine had no consistent effects on the blood sugar when administered intravenously, there was a small but fairly consistent fall in the blood sugar. This evidence would support Cochrane's (1960) hypothesis that the level of leucine in the plasma normally exerts some control over the rate of insulin release. If this hypothesis is correct, then the controlling effect must normally be small. However, in certain conditions-genetic predisposition, islet-cell tumours, and during sulphonylurea therapy-the normal effect of leucine is magnified.

The sensitizing effect of the sulphonylureas may be due to a variety of effects, but the two most likely hypotheses would seem to be $(a)$ that the drugs increase leucine uptake by the islets, or (b) that by stimulating insulin clearance from the islets they render the mechanisms of control of insulin production more sensitive to changes in plasma leucine (or glucose). The latter situation might apply with $\beta$-cell adenomata, where insulin synthesis and release are also increased by leucine. Our studies lend no support to the first hypothesis. Only in unphysiological amounts does tolbutamide affect in vitro leucine metabolism by muscle. And, although the autoradiographic method is only likely to reveal relatively gross differences in leucine uptake by the islets, our small study did not reveal any such difference. The method of studying the metabolism of isolated mammalian islets (Keen et al., 1963) may offer a more sensitive method of studying both hypotheses.

\section{Summary}

After the administration of tolbutamide normal individuals become sensitive to the hypoglycaemic effect of the amino-acid L-leucine. This effect could not, however, be demonstrated after the administration of another hypoglycaemic drug, phenformin. In vitro studies with the rat diaphragm failed to reveal any effect of tolbutamide upon leucine metabolism except in concentrations greater than those achieved therapeutically. No difference could be demonstrated in the uptake of injected ${ }^{14} \mathrm{C}$ leucine by the pancreatic islets between control rats and rats given a previous injection of tolbutamide or insulin, respectively.

The significance of these results is discussed.

We wish to acknowledge the help of Mr. K. Twinn, who prepared the autoradiographs. We are also grateful for the technical assistance of Miss Diana Bruce and Miss Brenda Sargeant.

\section{REFERENCES}

Bornstein, J. (1957). Nature (Lond.), 179, 534.

Butterfield, W. J. H., Arab, M. M. H., Buckle, A. L. J., Chlouverakis, C., Hanley, T., Mahler, R. F., and Whichelow, M. J. (1962). Diabetes,

11, Suppl. p. 43. W. Wright, P. H., and Woolf, L. I. (1960). Nature (Lond.), 188, 70.

Cochrane, W. A. (1960). 7. Dis. Child., 99, 476

Payne, W. W., Simpkiss, M. J., and Woolf, L. I. (1956). F. clin. Invest., 35, 411 .

Danowski, T. S., Bonessi, J. V., Balash, W. R., and Moses, C. (1962). Metabolism, 11, 556.

Fajans, S. S., Knopf, R. F., Floyd, J. C., jun., Power, L., and Conn, J. W. (1963). F. clin. Invest., 42, 216.

Power, L., Gwinup, G. W., Knopf, R. F., and Conn, J. W. (1960). 7. Lab. clin. Med., 56, 810 .

7. Lab. clin. Med., 56, 810. Chem., 120, 51.

Hoffman, W. S. (1937). F. biol. Chem., 120, 51. Demonstration to the Keen, H., Jarrett, R. J., and Sells, R. (1963). Dem

Manchester, K. L., and Young, F. G. (1958). Biochem. F., 70, 297.

Schwartz, T. B., Flanagan, G. C., Stuppy, G. W., and Tarum, D. W. (1959). ₹. Lab. clin. Med., 54, 944

Weisenfeld, S., and Goldner, M. G. (1961). Amer. F. Med., 31, 659.

Yalow, R. S., and Berson, S. A. (1960). F. clin. Invest., 39, 1157.

\title{
Acetohexamide in Treatment of Diabetes Mellitus
}

\author{
D. A. D. MONTGOMERY,* M.D., M.R.C.P. ; G. K. RASTOGI, † M.B., B.S., M.R.C.P., M.R.C.P.ED. \\ J. A. WEAVER, $\ddagger$ M.D., M.R.C.P.
}

Brit. med. F., 1964, 1, 868-871

The sulphonylureas tolbutamide and chlorpropamide have established their place as safe and effective drugs in the oral therapy of selected patients with stable diabetes mellitus. Nevertheless, the search for new hypoglycaemic drugs continues, and it is essential to subject each compound to critical study before it receives widespread clinical acceptance. Recently a new oral hypoglycaemic drug, acetohexamide ( $N$-p-acetylbenzenesulphonyl- $N$-cyclohexylurea), has become available and pre-

\footnotetext{
* Physician-in-Charge, Sir George E. Clark Metabolic Clinic, Royal Victoria Hospital, Belfast.

† Registrar, Sir George E. Clark Metabolic Clinic, Royal Victoria Hospitai, Belfast. Present address: Department of Endocrinology, AllIndia Institute of Medical Sciences, New Delhi.

‡ Physician, Sir George E. Clark Metabolic Clinic, Royal Victoria Hospital, Belfast.
}

liminary reports have been published (Balodimos et al., 1961 ; Weller et al., 1962 ; Maha et al., 1962 ; Owen, 1962 ; Boshell et al., 1962 ; Dobson, 1962). The purpose of this paper is to record our own experience with acetohexamide in treating 50 cases of diabetes mellitus.

\section{Methods}

The trial was designed to test the safety and effectiveness of the drug in patients attending the diabetes clinic at the Royal Victoria Hospital, Belfast. No attempt was made to compare its potency specifically with other hypoglycaemic drugs, although experience was gained in this respect. 
The patients ( 40 women and 10 men) were aged 42 to 77 , with an average of 59.3 years. The duration of their diabetes was less than one year to 24 years, with an average of threeand-three-quarters years. Their weights varied from 105 to $216 \mathrm{lb}$. (47.6 to $98 \mathrm{~kg}$.), with an average of $146 \frac{1}{2} \mathrm{lb}$. (66.5 kg.). They had been on treatment with diet alone, or diet combined with oral therapy or insulin. Table I shows their distribution these, patients were seen frequently at first, and had regular haematological and biochemical examinations during the course of the investigations. The tests performed, both before treatment and one, three, and six months later, included a total and differential white-cell count, a red-cell count, and examination of a blood film, blood urea, serum bilirubin, serum alkaline phosphatase, serum glutamic pyruvic transaminase (S.G.P.T.),

TABLE I

\begin{tabular}{|c|c|c|c|c|c|c|c|c|c|c|c|c|c|}
\hline \multirow{2}{*}{ Previous Therapy } & & \multirow{2}{*}{$\begin{array}{l}\text { No. of } \\
\text { Patients }\end{array}$} & \multicolumn{3}{|c|}{$\begin{array}{l}\text { Weight* before } \\
\text { Acetohexamide }\end{array}$} & \multicolumn{2}{|c|}{$\begin{array}{l}\text { Mean Blood-glucose } \\
\text { Values (mg./100 ml.) }\end{array}$} & \multicolumn{3}{|c|}{$\begin{array}{c}\text { Weight after } \\
\text { Acetohexamide }\end{array}$} & \multicolumn{3}{|c|}{ Response } \\
\hline & & & $\begin{array}{c}\text { Over- } \\
\text { weight }\end{array}$ & $\begin{array}{c}\text { Standard } \\
\text { Weight }\end{array}$ & $\begin{array}{l}\text { Under- } \\
\text { weight }\end{array}$ & a.m. & p.m. & $\begin{array}{l}\text { Weight } \\
\text { Gain }\end{array}$ & $\begin{array}{l}\text { Weight } \\
\text { Constant }\end{array}$ & $\begin{array}{l}\text { Weight } \\
\text { Loss }\end{array}$ & Good & Fair & Poor \\
\hline 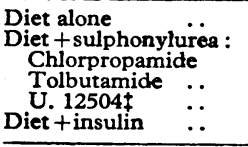 & $\begin{array}{l}\cdots \\
\cdots \\
\cdots \\
\cdots\end{array}$ & $\left.\begin{array}{l}31 \\
6 \\
4 \\
2\end{array}\right\}_{7} 12$ & $\begin{array}{l}6 \\
2 \\
\end{array}$ & $\begin{array}{l}14 \\
5 \\
5\end{array}$ & $\begin{array}{r}1 \\
- \\
\end{array}$ & $\begin{array}{l}222 \\
202 \\
163 \\
\end{array}$ & $\begin{array}{l}222 \\
185\end{array}$ & $\begin{array}{l}2 \\
2\end{array}$ & $\begin{array}{l}8 \\
3\end{array}$ & $\begin{array}{l}2 \\
2 \\
\end{array}$ & $\begin{array}{l}7 \\
5 \\
\end{array}$ & $\begin{array}{l}3 \\
1\end{array}$ & $\begin{array}{l}2 \\
1 \\
\end{array}$ \\
\hline Total & .. & 50 & 21 & 24 & 5 & & & 15 & 24 & 11 & 35 & 6 & $7 \ddagger$ \\
\hline
\end{tabular}

* Classified with reference to the Table of Life Extension Institute of New York. † Excludes 2 patients in whom response could not be assessed (see text).

† Another oral hypoglycaemic sulphonylurea recently tried but withdrawn by the manufacturers.

according to previous treatment and their weight before acetohexamide was given. Those on diet alone had completed at least six weeks' dietary restriction before the drug was administered, except for two patients. One of these had mild diabetic ketosis, while the other's initial blood-glucose levels suggested that diet alone was unlikely to be successful.

The diet prescription generally consisted of 1,500 calories (carbohydrate portion $150 \mathrm{~g}$.) unless the patient exceeded his or her standard weight for height and age (Tables of Life Extension Institute of New York). In obese patients diets of 1,200 calories (120 g. carbohydrate), or 1,000 calories (100 g. carbohydrate) were substituted. A few patients were underweight, and these together with a number of men engaged in heavy work were given diets of up to 2,100 calories $(210 \mathrm{~g}$. carbohydrate). The number of calories given was less than 1,500 in 14 cases ; 1,500 in 24 cases; and more than 1,500 in 12 cases. All patients were interviewed by the clinic dietitian and had the value of standard food portions and estimation of diet from a simplified table of food values explained to them. Regular supervision of their dietary intake was also carried out by the dietitian. Those who had been on insulin previously had the necessary adjustment made to their diet when transferred to acetohexamide.

Patients were reviewed at fortnightly and later at monthly and three-monthly intervals. Postprandial ( $2 \frac{1}{2}-3$ hour) bloodglucose levels were estimated from venous blood samples by the Technicon auto-analyser. Mid-morning (11 to 11.30 a.m.) and mid-evening ( 8.30 to 9 p.m.) results were available before each visit. In addition, all brought a record of their urine tests, carried out with " clinitest" tablets on freshly voided samples (fasting and before the main meals of the day) during the seven days preceding the clinic visit.

The criterion for beginning acetohexamide treatment for patients on diet alone was a constant postprandial blood-glucose level above $150 \mathrm{mg} . / 100 \mathrm{ml}$. In fact, the majority had average blood-glucose levels in excess of $200 \mathrm{mg} . / 100 \mathrm{ml}$. Patients already receiving a sulphonylurea were either changed to acetohexamide because of an unsatisfactory response (four cases) or were chosen randomly (eight cases). Those taking insulin were tried on acetohexamide if they were thought to be suitable for oral treatment. The mean blood-glucose values for the three groups are recorded in Table $I$.

Acetohexamide was given in a single daily dose of $500 \mathrm{mg}$. at first, unless the severity of the symptoms or the bloodglucose values suggested the need for a larger dose, when $\mathbf{7 5 0}$ or $1,000 \mathrm{mg}$. was administered. At later visits the dose was adjusted in accordance with the blood-glucose and urine test results.

Great importance was attached to the detection of possible toxic effects of the drug throughout the trial. To test for serum glutamic oxaloacetic transaminase (S.G.O.T.), serum pseudocholinesterase, and serum protein electrophoresis.

\section{Results}

The criteria of response which we use in our clinic to assess diabetic control, and on which the results of treatment with acetohexamide were judged, are shown in Table II. The results achieved are recorded in Table I, where it can be seen that 35 $(70 \%)$ obtained a good response, $6(12 \%)$ a fair response, and 7 (14\%) a poor response. In two patients the response could not be assessed (indefinite response) because one received only a single dose of the drug and the other was flagrantly uncooperative over the restriction advised in his diet.

TABLE II

\begin{tabular}{|c|c|c|c|c|}
\hline \multicolumn{3}{|c|}{ Response } & $\begin{array}{c}\text { Blood-glucose Levels } \\
\text { (Mean 2t-3 hr. Postprandial) }\end{array}$ & Glycosuria \\
\hline $\begin{array}{l}\text { Good } \\
\text { Fair }\end{array}$ & . & 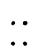 & $\begin{array}{l}\text { Less than } 150 \mathrm{mg} . / 100 \mathrm{ml} . \\
150-200 \mathrm{mg} . / 100 \mathrm{ml} .\end{array}$ & $\begin{array}{l}\text { None } \\
\text { Occasional, and always less }\end{array}$ \\
\hline Poor & $\ldots$ & $\ldots$ & More than $200 \mathrm{mg} . / 100 \mathrm{ml}$. & $\begin{array}{l}\text { Considerable, and usually } \\
\text { more than } 2 \mathrm{~g} . / 100 \mathrm{ml} \text {. }\end{array}$ \\
\hline
\end{tabular}

All underweight patients gained weight if they showed a good or fair response to the drug. Of 45 patients who were either overweight or of standard weight 10 gained weight, but none gained more than $6 \mathrm{lb}$. $(2,722 \mathrm{~g}$.) except for the patient who was included in the indefinite-response category.

Table III shows that $37(74 \%)$ patients were still taking acetohexamide, while $13(26 \%)$ were on insulin, or another

\begin{tabular}{|c|c|c|c|c|c|}
\hline $\begin{array}{l}\text { Duration of } \\
\text { Acetohexamide } \\
\text { Treatment }\end{array}$ & $\begin{array}{c}\text { Still on } \\
\text { Aceto-- } \\
\text { hexamide }\end{array}$ & $\begin{array}{c}\text { Transferred } \\
\text { to } \\
\text { Insulin }\end{array}$ & $\begin{array}{c}\text { Transferred } \\
\text { to } \\
\text { Another } \\
\text { Sulphonyl- } \\
\text { urea }\end{array}$ & $\begin{array}{l}\text { Transferred } \\
\text { to Diet } \\
\text { Alone }\end{array}$ & Total \\
\hline 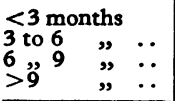 & $\begin{array}{r}-4 \\
11 \\
22\end{array}$ & $\begin{array}{r}3 \\
1 \\
1 \\
-\end{array}$ & $\begin{array}{r}2 \\
1 \\
2 \\
-\end{array}$ & $\frac{2}{1}$ & $\begin{array}{r}7 \\
6 \\
14 \\
23\end{array}$ \\
\hline Total $\quad$. & 37 & 5 & 5 & 3 & 50 \\
\hline
\end{tabular}

sulphonylurea, or on diet alone. Twenty-three patients have taken acetohexamide for more than nine months.

Dose of Acetohexamide.-Those who responded well to treatment required 250 to $500 \mathrm{mg}$. of acetohexamide daily except for one patient who needed $750 \mathrm{mg}$. All those showing a fair response required a larger dose (750 or $1,000 \mathrm{mg} . /$ day) and two were given metformin (dimethyldiguanide) $500 \mathrm{mg}$. three 
times daily in addition. Of the patients who showed a poor response, three were tried on $1,500 \mathrm{mg}$. daily and two of them were given metformin in combination with the acetohexamide. The average daily dose at the end of six months in all patients was $500 \mathrm{mg}$./day.

\section{Side-effects}

The side-effects and variation in the biochemical tests, their severity, frequency, and final outcome, are shown in Table IV. One of the three patients complaining of gastro-intestinal symptoms received a single dose of 1,000 mg., which was followed by vomiting and abdominal cramps. She was treated later with another sulphonylurea without ill effect. Hypoglycaemic symptoms (confirmed by a low blood-glucose level) occurred in four patients, and in three they were severe enough to stop treatment. One patient showed a transient fall in the total white-cell count from 6,200 to $3,300 /$ c.mm. but with no corresponding fall in the granulocytes. A week later the count was found to be normal, and it remained so during continuation of the acetohexamide treatment.

\begin{tabular}{|c|c|c|c|c|c|}
\hline & $\begin{array}{c}\text { Total } \\
\text { No. } \\
\text { Affected }\end{array}$ & $\begin{array}{c}\text { Mild } \\
\text { Drug } \\
\text { Continued }\end{array}$ & $\begin{array}{c}\text { Severe } \\
\text { Drug } \\
\text { Stopped }\end{array}$ & Transient & Persistent \\
\hline $\begin{array}{ll}\text { Side-effects : } & \\
\text { Gastro-intestinal } & \ldots \\
\text { Hypoglycaemia } & \ldots \\
\text { Leucopenia } & .\end{array}$ & $\begin{array}{l}3 \\
4 \\
1 *\end{array}$ & $\begin{array}{l}2 \\
1 \\
1\end{array}$ & $\begin{array}{r}1 \\
-\end{array}$ & $\begin{array}{l}2 \\
1 \\
1\end{array}$ & $\underline{3}$ \\
\hline $\begin{array}{c}\text { Alteration in biochemi- } \\
\text { cal tests : } \\
\text { Rise in serum alka- } \\
\text { line phosphatase } \\
a_{2} \text {-Globulin increase } \\
\text { Fall in pseudocholin- } \\
\text { esterase } \\
\text { Rise in blood urea }\end{array}$ & $\begin{array}{r}24 \\
31 \\
9 \\
9\end{array}$ & $\begin{array}{r}24 \\
31 \\
9 \\
9\end{array}$ & $\begin{array}{l}- \\
-\end{array}$ & $\begin{array}{r}9 \\
18 \\
9 \\
9\end{array}$ & $\begin{array}{r}15 \\
13 \\
-\end{array}$ \\
\hline
\end{tabular}

Alteration in the biochemical investigations was often noted. $A$ rise in the serum alkaline phosphatase and an increase in the $\alpha_{2}$-globulin fraction of the serum proteins were seen in 24 and 31 patients respectively. Ten patients had a raised serum alkaline phosphatase and 18 a raised $\alpha_{2}$-globulin before acetohexamide was started, and in these it remained elevated subsequently. The highest serum alkaline phosphatase level recorded during treatment was 25 King-Armstrong (K.A.) units (the normal upper limit in our laboratory is 13 K.A. units), but one patient had a level of 28 K.A. units before treatment was started. The elevated $\alpha_{2}$-globulin levels (normal range for our laboratory, $0.14-0.66 \mathrm{~g} . / 100 \mathrm{ml}$.) varied between 0.68 and $0.79 \mathrm{~g} . / 100 \mathrm{ml}$. before treatment, while $0.96 \mathrm{~g} . / 100 \mathrm{ml}$. was the highest level recorded after treatment.

Analyses of variance were applied to the serial levels of serum alkaline phosphatase and $\alpha_{2}$-globulin after dividing the patients into three groups: (1) those who had two estimations (before treatment and after one month), (2) those who had three estimations (before and after one and three months), and (3) those who had four estimations (before and after one, three, and six months). Statistically significant $(P<0.01)$ changes were found only in the three- and six-months alterations in the level of the serum alkaline phosphatase. The other comparisons were not significant $(P>0.05)$ for changes in alkaline phosphatase and $\alpha_{2}$-globulin.

A transient fall in the pseudocholinesterase value below 60 units $/ 100 \mathrm{ml}$. (lower limit of normal value in our laboratory) was found in nine patients. A raised blood urea, above $40 \mathrm{mg}$./ $100 \mathrm{ml}$. (upper limit of normal), was found in five patients initially. In three it returned to within normal limits during the trial. In four other patients it rose (highest value $72 \mathrm{mg}$./ $100 \mathrm{ml}$.) during acetohexamide treatment, but these findings are not statistically significant.
One patient developed oedema of her feet, painful breasts, and malaise after taking acetohexamide for four months. Her $\alpha_{2}$-globulin was raised and her sedimentation rate increased. Her complaints and biochemical abnormalities ceased when the acetohexamide was withdrawn.

\section{Discussion}

These results and the experience of others show that acetohexamide is an effective drug for the oral therapy of diabetes mellitus. As with other hypoglycaemic agents strict adherence to a correct diet plays an important part. A gain in weight, except in those who are underweight, may be the first sign of dietary indiscretion, and it often appears before there is loss of adequate diabetic control.

Acetohexamide in a single daily dose of $1,000 \mathrm{mg}$. after breakfast seems to be an effective therapeutic dose. We do not think it is advantageous to prescribe larger doses, because the administration of 1,250 or $1,500 \mathrm{mg}$. daily did not improve the degree of control in those who showed a fair or poor response to the lower dose. The addition, however, of metformin $500 \mathrm{mg}$. twice or thrice daily improved the response in those failing to respond to acetohexamide alone. This drug appears to be as useful an adjunct to acetohexamide therapy as it does when used in combination with tolbutamide and chlorpropamide (Hadden et al., 1963). At the end of six months the average daily dose of acetohexamide was $500 \mathrm{mg}$. in patients showing a good or fair response to its administration.

On the basis of our previous experience with the sulphonylureas (Gorman and Weaver, 1959; Hadden et al., 1962) and the results of this trial we find $1,000 \mathrm{mg}$. of acetohexamide to be roughly equivalent to $2,250 \mathrm{mg}$. of tolbutamide and $500 \mathrm{mg}$. of chlorpropamide. Our results compare fairly closely with those of Owen (1962), who specifically studied the hypoglycaemic potency of these sulphonylureas in six " maturity onset" diabetics. He found the relative potencies to be: tolbutamide $1,000 \mathrm{mg}$., acetohexamide $437 \mathrm{mg}$., and chlorpropamide $166 \mathrm{mg}$. In animal experiments acetohexamide was found to be more potent than either tolbutamide or chlorpropamide (Maha et al., 1962).

Acetohexamide did not prove to be more effective than chlorpropamide in the six cases in which it was substituted for the latter drug, and on the present available evidence it does not appear to possess any advantages. Indeed, until the problem of the increase in the serum alkaline phosphatase level (which we discuss below) is solved, chlorpropamide seems to be the more acceptable. Acetohexamide did, however, improve the diabetic control in patients previously on tolbutamide. There may be an advantage, therefore, in using acetohexamide for patients who are less than adequately controlled on tolbutamide if chlorpropamide is thought inappropriate. Secondary failure to acetohexamide has not been observed in this series, although it has been reported to occur (Maha et al., 1962).

The incidence of toxic effects requiring the withdrawal of acetohexamide was not high. The drug had to be stopped in two patients, an incidence of $4 \%$. Gastro-intestinal symptoms in one patient seemed related specifically to the acetohexamide, since another sulphonylurea was taken without ill effect. Symptoms of general malaise, painful breasts, and oedema of the feet experienced by another have not been reported hitherto.

Three patients had their treatment stopped because of hypoglycaemia. This occurrence in two patients treated with a normal therapeutic dose within the first three months suggests that the preliminary period of six weeks' trial on diet may not always be long enough to separate those needing drug therapy from those likely to respond to diet alone. The hypoglycaemic symptoms were mild and easy to manage and could probably have been avoided by better patient-selection.

The fall in the total white-cell count seen in one patient was evidently an incidental and transient finding, for when 
the count was repeated a week later it was found to be normal and there was no recurrence. No other toxic effects in the blood-forming organs were noted.

The frequent alterations in the biochemical investigations were studied carefully, but statistically significant alterations were found only in the case of the serum alkaline phosphatase estimations at the third and sixth months of treatment. Camerini-Davalos et al. (1962) have reported that the serum alkaline phosphatase and other liver-function tests are abnormal in $10 \%$ of diabetic patients irrespective of therapy. In this series nearly half the group showed a rise in the alkaline phosphatase during some stage of the trial, while in $20 \%$ (all but one of whom were untreated) the level was raised before acetohexamide was started. We do not know what importance to attach to this observation, which has been described by other workers (Boshell et al., 1962 ; Field and Tyroler, 1963). Our patients showed no clinical evidence of ill-health, and we did not discontinue the drug as a result of this finding. Certainly, the evidence of an abnormal alkaline phosphatase level suggests a possible deleterious effect of the drug on the liver, but we did not observe any other significant biochemical disturbance or clinical findings to support this conclusion. It is conceivable that acetohexamide might possess an extrahepatic activity, so that an effect on kidney or osteoblast metabolism remains a hypothetical possibility. It is clear that further investigation into the importance or otherwise of the alkaline phosphatase response during acetohexamide therapy is needed. It is because of this finding that we hesitate to give the drug our unqualified recommendation.

\section{Summary}

An investigation into the clinical use of acetohexamide in the treatment of 50 patients with diabetes mellitus has been carried out : $35(70 \%)$ showed a good response, $6(12 \%)$ a fair response, $7(14 \%)$ a poor response, while the response could not be adequately determined in 2 .

Toxic effects of acetohexamide were not severe and treatment had to be discontinued in two (4\%) A statistically significant rise in the level of the serum alkaline phosphatase was found at three and six months in treated patients. This finding could not be correlated with any clinical disturbance or other hepatotoxic effects and its cause is not understood. Nevertheless its occurrence underlines the necessity for more extensive clinical trials before acetohexamide can be recommended unreservedly for treating patients with diabetes mellitus.

We are grateful to Dr. F. Latham, of Messrs. Eli Lilly, for generous supplies of acetohexamide used throughout the trial; to Mr. J. B. Merrett, of the department of social and preventive medicine, Queen's University of Belfast, for advice about the statistical analyses; and to Dr. M. G. Nelson and Mr. D. W. Neill for the haematological and biochemical investigations which were carried out in their respective laboratories. We wish to thank the clinic dietitians and other members of the metabolic unit staff for their assistance and Miss L. Carroll for secretarial help.

\section{REFERENCES}

Balodimos, M. C., Stimson, W. H., Tanner, D. C., Reid, J. A., and Williams, R. H. (1961). Metabolism, 10, 1063

Boshell, B. R., Wilensky, A. S., Barrett, J. C., and Almon, J. V. (1962). Clin. Pharmacol. Ther., 3, 750 .

Camerini-Davalos, R., Marble, A., and Muench, H. (1962). New Engl. F. Med., 266, 1349 .

Dobson, H. L. (1962). Metabolism, 11, 1282.

Field, J. B., and Tyroler, S. A. (1963). Diabetes, 12, 252.

Gield, J. B., and Tyroler, S. A. (1963). Diabetes, 12, 252.

Hadden, D. R., Montgomery, D. A. D., and Weaver, J. A. (1962). Diabetes, 11, 91

Maha, G. E K (1963). Irish f. med. Sci., p. 469.

Diabetes, 11, 83

Owen, J. A. (1962). Metabolism, 11, 475.

Weller, C., Donesa, A., and Linder, M. (1962). Ibid., 11, 551.

\title{
Restenosis of Mitral Valve: A Study of 100 Cases Treated by Operation
}

\author{
J. R. BELCHER,* M.S., F.R.C.S. ; R. L. GUPTA,* † M.S., F.R.C.S., F.R.C.S.ED.
}

Brit. med. F., 1964, 1, 871-875

Papers about restenosis of the mitral valve have been principally concerned with the incidence and cause of the condition. The results of operative treatment have been mentioned only in passing.

As an increasing number of patients who were operated on before the introduction of transventricular valvotomy by Logan et al. (1962) are now presenting with a recurrence of their symptoms, it seemed worth while to find out what had happened to those who had undergone a second operation, and, if possible, what factors had an adverse influence on the results.

\section{Material}

We have studied 100 patients who have had second operations for mitral stenosis. The results have not been as good as those

* From the Middlesex and London Chest Hospitals.

$\uparrow$ Smith and Nephew Fellow in Surgery. obtained after primary valvotomy, and the various factors which may have accounted for this have been considered.

The first patient in the series had his second operation in 1956, and the last in September 1961. There were 15 men and 85 women, their average age at the time of the second operation being 41 , with extremes of 25 and 61 .

\section{Operation}

Sixty-six of the patients had their first operation done by one of us (J.R. B.) ; all of these came from a group of 376 patients whose valvotomy had been carried out by the finger-and-knife method, giving an incidence of restenosis of $17.6 \% \mathrm{so}$ far. The remainder had their first operation done elsewhere. One patient had a third valvotomy. Her second operation was done with the transventricular dilator; this was an early case, and it is now known that the dilatation was quite inadequate. Apart from this case, no patient who has had a valvotomy by 